\title{
Study on Tourist Satisfaction of Xijiang Miao Village from The Perspective of Landscape Gene
}

\author{
Shulin Xiao ${ }^{1}$, Yanling Huang ${ }^{1, *}$, Shengfeng Luo ${ }^{1}$ and Jingjing Wang ${ }^{1}$ \\ ${ }^{1}$ College of Tourism \& Landscape Architecture, Guilin University of Technology, Guilin, China.
}

\begin{abstract}
Analyzing the factors that affect tourist satisfaction can guide the sustainable development of tourist destination to a certain extent. In order to study the influence of Landscape Gene on the tourist satisfaction, the model of the structural equation was constructed by constructing the identification system and constructing the model of the structural equation. The results show that the characteristics of the building and the characteristics of the folk custom are positively influenced. The characteristics of the faith have a negative effect on the satisfaction of the tourists, and the correlation coefficient is prominent. The characteristics of the environment have a negative impact on tourist satisfaction. The effect of the folkcustom character on tourist satisfaction is the most significant.
\end{abstract}

\section{Introduction}

With the development of tourism, the national village is becoming a popular tourist destination. Rural landscape tourism and ethnic cultural tourism in ethnic villages are the inevitable result of tourism development. However, the tourism demand of domestic tourists is constantly escalating, the lack of national connotation of intangible cultural landscape has been unable to meet the needs of tourists. The cultural landscape of ethnic tourism villages needs to be deeply interpreted, and the cultural characteristics accumulated in national history need to be protected.

Landscape is the main carrier of tourism formation, and culture is an important part of landscape formation [1]. American geographer Sauer(1925) took the lead in defining cultural landscape as a kind of human activity style attached to natural landscape [2]. Professor Liu Peilin(2003) took the lead in putting forward the concept of cultural landscape gene [3]. His team carried out a series of related continuous research. Through landscape genetic literature review, it can be found that the research hot spots of landscape gene are mainly focused on the traditional settlement zoning research [4-5], landscape gene recognition [6-8], landscape gene mapping combined with GIS technology [9-10], landscape gene expression and its application in practical planning and construction [11]. However, most of the related studies focus on landscape, residents and other local factors, ignoring the role of tourists in landscape gene development. Based on the visitors perception, the paper probes into the influence of the landscape gene on the satisfaction of the tourists, which is beneficial to the development of the village.

\section{General situation and research hypothesis}

\subsection{Overview of the study area}

Xijiang Miao village is located in the northeast of Leishan County, with more than 1300 households. The Miao population accounts for $99.5 \%$ of Xijiang Miao village. In the history of Xijiang Miao Village, the Miao nationality has a history of more than 1700 years, and it is the largest settlement of the Miao nationality in the world. In 2018, the number of visitors to Xijiang Miao Village is up to 553.27 million, which is an important group affecting the tourism development. As a typical tourist development of the ethnic village, Xijiang Miao Village has a large number of tourists. Therefore, the influence of the landscape gene on the satisfaction of the tourists is discussed as a study point, and it has a certain typicality.

\subsection{Research hypothesis}

Based on existing research results, combined with the cultural landscape characteristics, and from the point of view of material landscape gene and non-material landscape gene, the landscape gene recognition system of Xijiang Miao Village was constructed[12]. The landscape gene recognition system of Xijiang Miao Village is composed of four dimensions: environmental characteristics, architectural features, belief characteristics and folk custom characteristics., Therefore, this paper uses the structural equation model to explore the mechanism of landscape genes on tourist satisfaction through four dimensions. Tourist satisfaction

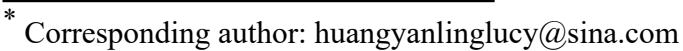


is mainly measured from three aspects: the willingness to revisit, the satisfaction of landscape and the satisfaction of landscape protection.

\subsubsection{Environmental characteristics}

Environment is the external condition that affects the breeding, development and inheritance of landscape genes. Therefore, unique environment can create different landscape genes. Environmental characteristics are the important parts of the local landscape gene recognition system. The road network, ecological environment, layout and other landscape elements of ethnic villages have been carefully planned and designed, which contains profound cultural implications. Therefore, the landscape genes contained in environmental characteristics are essential. The environmental characteristics are mainly composed of four testable variables: overall layout, environmental factors, street landscape and farmland landscape. It is proposed that $\mathrm{H} 1$ : The environmental characteristics have a significant positive impact on tourist satisfaction.

\subsubsection{Building characteristics}

Architecture is one of the most significant landscapes reflecting the national features, and the architectural landscape also contains cultural diversity. Therefore, the landscape gene excavation of national characteristic architecture is especially important. The building features mainly include two parts of the residential building and the public building, which can reflect the various aesthetic culture of the residents, and the main public buildings represent the traditional and mainstream aesthetic collection of the people. From material selection, structural design and partial decoration to the completion of the house in Xijiang Miao village, a complete set of cultural customs has been formed. The building contains the wisdom and wisdom of the predecessors, including the local belief culture, taste and aesthetics. The landscape of the foot tower, which is known for Xijiang Miao village, is one of the cultural witness. The architectural features are mainly composed of five testable variables: residential modeling, plane structure, local decoration, building materials and public buildings. It is proposed that $\mathrm{H} 2$ : The building characteristics have a significant positive impact on tourist satisfaction.

\subsubsection{Belief characteristics}

National belief is the core of national spirit and national culture. The belief characteristics of Xijiang Miao village mainly include natural worship, ancestor worship and national totem. The main natural worship objects of Miao people are heaven, earth, sun, moon, boulder, big tree, bamboo, mountain rock, bridge and so on. Under the influence of clan etiquette, ancestor worship occupies an important position. The belief totem of Xijiang Miao village mainly includes ox horn, maple, auspicious flower, butterfly and so on. However, tourists cannot understand the development process and national culture of the nation through the local belief culture. The characteristics of the belief are mainly composed of the natural worship, ancestor worship and measurable variable of the totem of Miao. It is proposed that H3: The belief characteristics have a significant negative effect on tourist satisfaction.

\subsubsection{Folk custom characteristics}

Ethnic characteristics contain the intangible cultural landscape genes. It is the main way for tourists to experience the local non-material culture. Folk custom characteristics are composed of six testable variables: insession entertainment, diet culture, Miao festival, traditional craftsmanship, Miao language and Miao dress. It is proposed that H4: The folk-custom characteristics have a significant positive impact on tourist satisfaction.

\section{Study design}

\subsection{Questionnaire design and analysis methods}

Through field investigation and literature review, the landscape gene system of Xijiang Miao Village was identified and determined. Through interviews with tourists and tourism practitioners, the latent variables of observation variables such as environmental characteristics, architectural characteristics, belief characteristics and folk characteristics were concluded. Finally, the content of the questionnaire was set based on the above results. The tourist questionnaire includes three parts: satisfaction, landscape gene perception and the basic situation of the interviewees. Among them, tourist satisfaction is mainly measured by four dimensions: environmental characteristics, architectural features, belief characteristics and folk characteristics. Tourist satisfaction and landscape gene perception were measured by Likert 5-point scale.

The data were obtained mainly through the distribution of tourist questionnaires in early May 2019 and mid-October 2019. A total of 329 questionnaires were distributed during the survey, among which 340 were effective, with an effective rate of $96.76 \%$. After the questionnaire was sorted out, SPSS software was used for descriptive statistical analysis, exploratory factor analysis, etc. Finally, Amos software was used to verify the model and assumptions.

\subsection{Model setting}

The structural equation model was used to investigate and analyze the relationship between landscape genes and tourist satisfaction. Structural equation model is a statistical method based on covariance matrix of variables to analyze the relationship between variables. As a statistical method to discuss macro law from microscopic phenomena, the purpose of structural equation model is to establish the structural relationship between latent variables. 
Based on the above four dimensions of landscape gene dimensions as the main variables, combined with the needs of structural equation model (SEM) research, this paper puts forward the conceptual model of tourist satisfaction, as shown in Fig. 1.

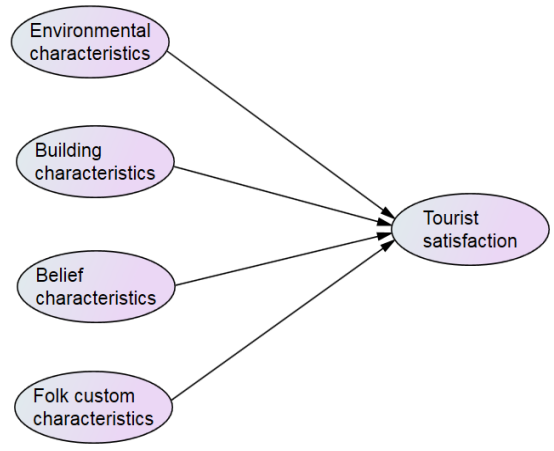

Fig. 1. Conceptual model of tourist Satisfaction.

\subsection{Demographic characteristics of population}

The statistical analysis software SPSS22 is used to analyze the tourist questionnaire. The number of men and women is equal, accounting for $50.8 \%$ and $49.2 \%$ of the total respectively. The age of the interviewees was mostly between 18 and 30 years old, accounting for $40.7 \%$. Tourists in Xijiang Miao village had a high level of education, accounting for $63.5 \%$ of the total number of students in college and above. The population with the largest proportion of occupation in Xijiang Miao village is the staff of enterprises and institutions.

\section{Research results and analysis}

\subsection{Construction and analysis of structure model}

For 21 measurement items that affect tourist satisfaction, the Cronbach's $\alpha$ coefficient is 0.896 . The Cronbach's $\alpha$ coefficient of environmental characteristics, building characteristics, belief characteristics, folk customs characteristics and tourist satisfaction dimension were $0.672,0.748,0.847$ and 0.839 . The results show that the tourist satisfaction scale has good reliability and stability. KMO value is 0.919 , which indicates that the factor analysis of the data is better. The estimated values of variable parameters are all above 0.5 , which indicates that the variables can be well explained by the measurement items of each dimension. The $\mathrm{P}$ values of variables have passed the significance test.

There are 21 observation variables in the model, and the degree of freedom of the model is $231-47=184$. The overall fitting degree of this study is $\mathrm{X}^{2}=537.800$, $\mathrm{df}=184, \mathrm{X}^{2} / \mathrm{df}=2.923, \mathrm{p}<0.001, \mathrm{GFI}=0.866, \mathrm{AGFI}=0.832$, $\mathrm{RMSEA}=0.077$. According to the determination of the reasonable range of fitting degree indexes, all indexes of the model indicate that the model has a good data fitting ability. Therefore, this model can be used to study and analyze the path of the impact of landscape genes on tourist satisfaction in in Xijiang Miao village.
Table 1. Confirmatory factor molecule.

\begin{tabular}{|c|c|c|c|}
\hline Observation variable & $\begin{array}{c}\text { Cronbach's } \\
\alpha\end{array}$ & estimate & $\mathrm{P}$ \\
\hline Overall layout & \multirow{4}{*}{0.672} & 0.727 & 0.00 \\
\hline Environmental factors & & 0.658 & 0.00 \\
\hline Street landscape & & 0.557 & 0.00 \\
\hline Farmland landscape & & 0.565 & 0.00 \\
\hline Residential modeling & \multirow{5}{*}{0.748} & 0.775 & 0.00 \\
\hline Plane structure & & 0.562 & 0.00 \\
\hline Local decoration & & 0.587 & 0.00 \\
\hline Building materials & & 0.628 & 0.00 \\
\hline Public buildings & & 0.502 & 0.00 \\
\hline Natural worship & \multirow{3}{*}{0.624} & 0.549 & 0.00 \\
\hline Ancestor worship & & 0.638 & 0.00 \\
\hline Totem of Miao & & 0.747 & 0.00 \\
\hline $\begin{array}{c}\text { In-session } \\
\text { entertainment }\end{array}$ & \multirow{6}{*}{0.847} & 0.688 & 0.00 \\
\hline Diet culture & & 0.587 & 0.00 \\
\hline Miao festival & & 0.510 & 0.00 \\
\hline $\begin{array}{c}\text { Traditional } \\
\text { craftsmanship }\end{array}$ & & 0.510 & 0.00 \\
\hline Miao language & & 0.563 & 0.00 \\
\hline Miao dress & & 0.543 & 0.00 \\
\hline $\begin{array}{c}\text { Satisfaction of } \\
\text { landscape protection }\end{array}$ & \multirow{3}{*}{0.839} & 0.842 & 0.00 \\
\hline Willingness to revisit & & 0.754 & 0.00 \\
\hline $\begin{array}{l}\text { Satisfaction of } \\
\text { landscape }\end{array}$ & & 0.825 & 0.00 \\
\hline
\end{tabular}

\subsection{Model hypothesis test}

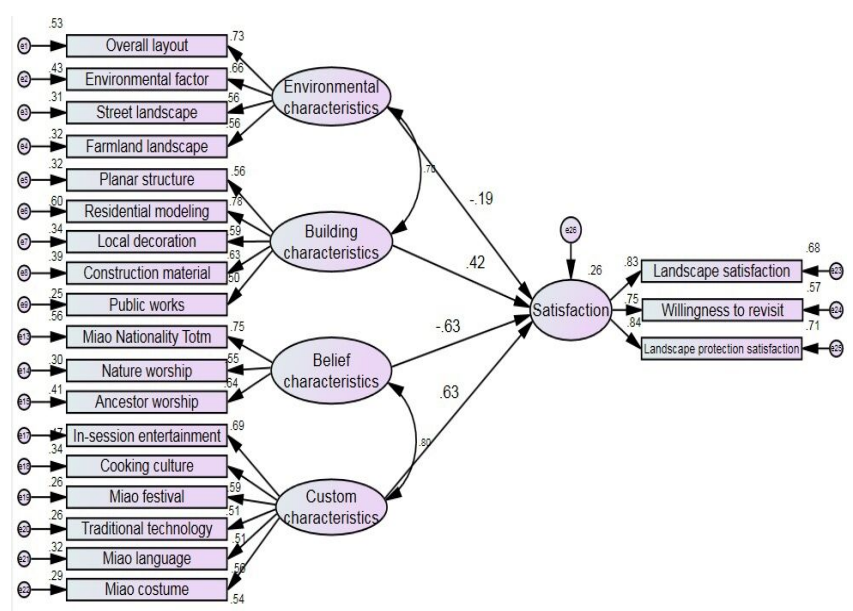

Fig. 2. Research model and hypothesis test results.

The path coefficient of the structural equation can reflect the relationship and influence degree between the latent variable and the observed variable. The larger the path coefficient is, the stronger the correlation is. According to the test results of model hypothesis (Fig. 2, Table. 2), the negative effect of environmental characteristics on 
tourist satisfaction was not significant $(\beta=-0.186, \mathrm{P} \leq$ 0.108 ), and the original hypothesis was rejected. Street landscape limits tourist satisfaction to a certain extent, so the commercial street landscape is contrary to environmental factors, terraces landscape and other factors, resulting in the original hypothesis is not valid. The architectural features have a significant positive effect on tourist satisfaction $(\beta=0.424, \mathrm{P} \leq 0.000)$, and the original hypothesis holds. Architectural landscape is a very representative local tourism landscape, the overall perception of tourists, satisfaction has a significant impact. The more obvious the national characteristics are, the higher the tourist satisfaction will be.

The characteristics of faith have a significant negative effect on the satisfaction of the tourists $(\beta=$ $0.629, \mathrm{P}=0.000$ ), and the original hypothesis is established. The stronger the religious atmosphere is, the lower the satisfaction of tourist will be. The folk-custom character has a significant positive effect on the satisfaction of the tourists $(\beta=0.630, P=0.000)$, and the original hypothesis is established. The characteristics of the folk custom are positively related to the satisfaction of the tourists. The stronger the national identity is, the higher the satisfaction of tourists will be. The influence of the folk-custom character on the satisfaction of the tourists is 0.630 , which is the highest of the four major dimensions, so the influence of the folk-custom character on the satisfaction of tourists is the most significant.

Table 2. Hypothesis test results of structural equation model.

\begin{tabular}{|c|c|c|c|c|}
\hline Suppose & $\begin{array}{c}\text { Standardized } \\
\text { path coefficients }\end{array}$ & $\mathrm{CR}$ & $\mathrm{P}$ & Conclusion \\
\hline $\mathrm{H} 1$ & -0.186 & -1.608 & 0.108 & refuse \\
\hline $\mathrm{H} 2$ & 0.424 & 3.636 & 0.000 & accept \\
\hline $\mathrm{H} 3$ & -0.629 & -7.372 & 0.000 & accept \\
\hline $\mathrm{H} 4$ & 0.630 & 7.813 & 0.000 & accept \\
\hline
\end{tabular}

\section{Conclusion}

\subsection{Tourists oppose excessive commercialization of local landscape}

Street landscape restricts tourist satisfaction, and commercial street landscape seriously affects tourist experience perception. The commercialization of local landscape is the inevitable trend of national village tourism development, but the national cultural landscape cannot reproduce at will. The tourism development of ethnic villages should respect culture as the starting point. Under the new background of cultural and tourism integration, it is necessary to promote the development, utilization, protection and evolution of ethnic cultural landscape.

\subsection{Folk landscape is most likely to affect tourist satisfaction}

The folk characteristic has the highest influence on the satisfaction of the tourists, so the national character of the folk landscape has a far-reaching influence on the tourists. The perception of the custom landscape of the national characteristic is reflected in its perception of the unique culture of the nation, and the cultural characteristics of the folk landscape are most likely to be perceived by the tourists. With the excavation and development of more folk landscape, the tourists perception of folk culture and the degree of recognition will be improved steadily. The folk custom is the product of the local history accumulation, and the development of tourism should respect the national culture.

\section{Acknowledgments}

Thanks for the help of the fund: The National Science Foundation of China Funded Project: Investigation on the Pro-poor tourism Effects and Influencing Mechanism on Settlement Space Evolution in Southwest Minority Villages (No.41661031). The Research launch Fund of Guilin University of Technology: Study on the Risk of Return to the Rural-village of the Southwestern Ethnic Tourism in the Sustainable Livelihood (GUTQDJJ2006039). The Open Fund of the key Laboratory (Research Base) of college of Tourism and Landscape Architecture, Guilin University of Technology: The Research and Countermeasures of Financial Support in the Tourism-oriented Poverty-relief Development in Guangxi (MZLY06).

\section{References}

1. Min Li, Lian Xie, Zui Hu. Journal of Hengyang Normal University, 36 (2015)

2. Sauer Carl. O. Recent Development in Cultural Geography. In: Hayes E D(1928)

3. Peilin Liu. Journal of Hengyang Normal University. 24 (2003)

4. Xiuying Shen, Peilin liu, Yunrendeng, et al. Geographical Research, 25 (2006)

5. Xiuying Shen, Peilin liu, Yunrendeng, et al.Journal of Liaoning University, 3 (2006)

6. Guozhi Yang. Graduate degree, Northwest normal university, ( 2014)

7. Shuaiqiang Cao, Yunyuan Deng, ZaitianYang, et al. Tropical Geography, 34 (2014)

8. Aiping Hou. Guizhou Ethnic Studies, 37 (2016)

9. Shuaiqiang Cao, Jiandan He, Yuanyun Deng, et al. Yunnan Geographic Environment Research, 28 (2016)

10. Zui Hu, Peilin liu. Human Geography, 23 (2008)

11. Zui Hu, Peilin liu, Ying Chen. Geography and GeoInformation Science, 25 (2009)

12. QiuyuChen, Junxi Yang, Shixian luo, et al. Tropical Geography, 39 (2019) 